\title{
Historical notes for an eventual regionalization of national development efforts in Sierra Leone, West Africa.
}

\author{
J. Veenstra
}

Received 20 June 1969

\section{Summary}

This is a study of the spatial consequences of socio-economic and politico-administrative changes during more than 150 years of pre-industrial developments in Sierra Leone, and is presented with the purpose of drawing up realistic regional development plans and strategies. During the various phases of pre-colonial settlement, an undifferentiated settlement and land-use pattern seems to have been characteristic between A.D. 1400 and 1600 , while from about 1600 to 1900 stockaded war-towns grew up dominating within their own areas of influence, and situated in the hinterlands of European coastal trading posts. By the $1920 \mathrm{~s}$, Freetown was becoming the central place and port of a developing system of urban centres superimposed upon the crystallized, but rural war-town pattern. This polarization depends on decisions made by traders, administrators, European commercial firms, and traditional and new élites, i.e. on commerce, subsistence and cash-crop farming, exploitation of minerals, and politicoadministrative changes under British colonial rule and since independence in 1961 . A subdivision of Sierra Leone is finally proposed into three main regions and nine subregions, each with its own development strategy.

\section{The first phases in the peopling of Sierra Leone: A.D. 1400-1900}

Friedmann $(1965$, p. 8), in sketching a simple model of how the cconomic space of a mation may be changed over several historical transitions, starts off by assuming an economically and socio-politically empty space to be colonized from the colonial mother country overseas. The oral traditions, however, of most of the fourteen tribes inhabiting Sierra Leone today suggest a pre-colonial immigration into the forested coastal areas, west and southwest of the Guinea Plateau of which the Koinadugu and Kono Plateaux form a part (Clarke et al., 1966). Only the Limba and Sherbro would seem to have been established in the country before A.D. 1400. Most of the other tribal groups came in a series of immigrative waves between the 16 th and the end of the 18 th Century, probably pressed into these largely uninhabited areas as refugees from the political upheavals which periodically shook the grassland empires of western Sudan. The first immigrants are said to have come to Sierra Leone during the 15 th Century as hunters and collectors rather than as agriculturalists in the tropical rain forests, though they may have practised shifting cultivation incidentally when circumstances allowed. These early immigrants arrived in small bands hunting wild animals felephants

t The author worked as FAO Land Use Planning Expert in Sierra Leone from April 1966 to October 1968, and participated in a Regional Development Planning Course at the Institute of Social Studies, The Hague, from October 1968 to July 1969. Since August 1969 the author is employed by Raidgevend Bureau Ir. B. W. Berenschot N.V., Management Consultants, Amsterdam Hengelo - Brussels - White Plains U.S.A. 
and bush cows), which, in contrast to game conditions today, were in plentiful supply. The small bands of hunters, little larger than the immediate family, used to set a pattern of life which was suited to the natural environment and which is still followed in some parts of Sierra Leone today, where trapping game and wild animals and fishing in the inland swamps and rivers is a less laborious way of earning a living than is cultivation.

One may suppose, however, that in this early period (A.D. 1400-1600) some temporary settlements had been developed into permanent sites, consequently attracting more outsiders so that more huts were set up, and that the settlement grew into a large village under the leadership of the original, would-be successful pioneer/hunter and his kin. As the size of the habitation increased, so did the need for fresh sources of food; and because hunting was the main occupation, expansion was favoured, for young men would venture off on their own and find fresh sites in the vicinity. But they retained their connection with the parent village, visiting it from time to time to pay homage. Thus, the picture emerges of numerous parent villages - each with its outlying hamlets, subsisting on a combination of hunting and growing a few grains of supplementary food -, which not only preceded in time but also made possible the second and more militant phase (A.D. 1600-1900) in the peopling of Sierra Leone.

For in fact each new wave of immigrants caused small-scale wars and the frequent alignment and re-alignment of tribal areas. Moslem tribes from the northern guinea savannah belt seem, thereby, to have taught the weaker tribes coming from southern directions how to enclose already existing villages with palisades, how to become overlords, in short, the needs of defence which are most responsible for fixing settlements at one site for long periods. As more and more immigrant groups arrived, a transition was subsequently made from temporary shelters of hunters at the one extreme to the fixed location, bush-fallowing agriculture at the other extreme - the latter being the common system for Sierra Leone today.

From accounts of 19 th-century explorers it is clear then, firstly, that the local chieftain and his company of warriors lodged within stockaded war-towns. Intertribal wars, caused by disputes over boundaries, resulted in regular killing of original, local leaders who were not able to withstand the invaders. Chiefs derived their power and authority mainly from their own prowess and that of their followers and warriors. Thereby it appears consequently as if relatively large hegemonies or confederacies grew up in certain regions under the general leadership and administrative control of a single, dominant chief whom the local rulers acknowledged as their overlord on socio-religious grounds or on agreement of reciprocal, military assistance in case of war.

Secondly, a tendency was observed to over-farm lands in the immediate vicinity of war-towns and their outposts, short fallows producing soil deterioration and food shortages. Competition for land and the fears of attack meant, that stockaded villages frequently exceeded by far the optimal size (about 500 inhabitants) governed by factors such as the quality of the land, the period of fallow necessary for soil regeneration, and the distance which farmers were willing to walk to the furthest farmed fields. Thirdly, an increase in the practice of slavery was noticed in order to staff satellites which were as a rule under the direct control of chiefs' followers, but still too far from the parent village to be considered by common people as being safe. Slavery - as an outcome of and reason for inter-tribal wars - made the cultivation of land feasible on a far larger scale than was likely by smaller groups of freemen whose needs could be satisfied by less arduous methods than were required in upland rice farming - which consequently became the predominant form of agricultural industry. 
Last but not least, slaves were also increasingly used as one of the few 'currencies' of universal value in exchanges for salt, tobacco, metalware, textiles and liquor with European slave traders entering Sierra Leone's interior from the coastal trading posts. The principal developments during the 18th and 19th Centuries along Sierra Leone's Atlantic coast were entirely tied up with the growth and decline of various European trading posts built initially as large slave and pirate settlements in the mouths and estuaries of creeks and rivers on defensible island sites, or under protection of powerful, locally dominant chiefs. In the later 19th Century trade was vigorous and complexly organized. Northern trade in particular had a distinctive character: caravans brought gold, ivory, rubber, hides and other goods from the Fouta Djallon, Kankan and Sangara in the Sudan, mostly for export through Freetown. War-towns where caravans gathered or where goods were exchanged, like Falaba, Kabala and Bumban, thrived on trade, their chiefs gaining prominence and strength. A regional trade also existed, and local people carried cloth, kolanuts and salt north on the long-distance routes leading into the Moslem savannah belt, or came down to the coast with cattle, leather goods or locally woven cloth. Thereby it was estimated about 1840 that some 15.000) slaves were shipped annually to America from numerous Spanish trading posts on the small islands dotting the creeks and adjacent waters of the Sherbro river's estuary, and from Turner's Peninsula.

\section{The rise of Freetown to primate city}

The quest for a perfect society which dominated the thinking of English humanitarians of the Enlightment of 18th-century Europe, led these Englishmen in the 1770s and 1780s to strive not only for Parliamentary reforms, establishment of schools for the working classes, etc. at home, but also to look abroad for abolishing the slave trade and making plans by which 'Africa would produce both wealth and happiness for mankind'.

Thus, the private initiative of a certain Granville Sharp and his humanitarian supporters seeking to create in the West African colony of future Sierra Leone a living memorial to their own enlightened values, led 300 to 400 free Black Poors who felt themselves lost in London, about 1200 former American slaves of African descent from Nova Scotia, North America, and about 600 members of an Afro-West Indian community which originated in Jamaica, to settle in the newly founded and planned, urban settlement of Freetown during the 1780s and 1790s. In 1808 Freetown and surrounding areas on the south end of the Sierra Leone river's estuary became the Crown Colony of Sierra Leone for which the British Crown assumed full responsibility, while in 1807 the slave trade abolition bill was approved by the British Parliament providing for the suppression of the slave trade, the capture of slaving vessels on the high seas and the enlistment or apprenticeship of the recaptured slaves in the city of Freetown or in nearby rural villages.

The picture of Freetown in 1807 , then, is that of a small community of about 2000 negro settlers, living a westernized life as near as possible to what their humanitarian benefactors expected of them. The Christian church organizations were centres of social life, providing a field of activities in which the free negro settler could acquire status and exercise leadership. These settlers mingled socially neither with the indigenous Africans around them, with whom they felt they had nothing in common, nor initially with the recaptured slaves disembarking in Freetown. This consciousness of negro settlers as being alien to all around them and the corresponding assumption 
that their way of life was to be copied in its westernized standards, was enhanced by the fact that they had the full backing of the British administration.

Government expenditures on construction of Freetown's roads, harbour works, warehouses, etc., and on administration to the extent that they were spent in winning tribal chiefs for maintaining order in their spheres of influence on the coast and in the interior, thus increasing the security of rivers, estuaries and Freetown's hinterland, were more conducive during following decades to the promotion of trade than of agriculture. Moreover, the agriculturalists under the recaptives and negro settlers used the land allotted to them by the British Government for shifting cultivation, which led automatically to soil erosion of the lateritic soils on the steep slopes of the mountainous Peninsula of Freetown. Trials of large-scale plantation agriculture around Freetown failed during the whole 19th Century, while the lure of slave trade caused an indifference to agriculture. Finally, the 19th Century laisser-faire philosophy helped to arrest agricultural development in the Sierra Leone Colony, but favoured trade and commerce.

Thus by the 1840 s commerce was basic to the Freetown city and its pattern of employment, while trade rose sharply in volume and value in the 1850 s and 1860 s with palm oil and kernels, kolanuts, groundnuts, gold and hides comprising the principal exports in substitution for slaves. The Freetown city population grew from about 2,000 inhabitants in 1807 to 20,000 in the 1860 s and 1870 s, while in these latter years the Crown Colony as a whole amounted to 40,000 or 50,000 inhabitants increasing to about 70,000 around 1890 .

Entrepôt and exchange functions were also performed, however, by private European trading posts along rivers and estuaries where in the early 19th Century exports and imports could be stored and exchanged as efficiently as in Freetown. Bonthe, for instance, with a population of about 4,000 inhabitants, still handled about $67 \%$ of the Sierra Leone palm kernel exports in 1899 because of its favourable location in the centre of the Sherbro river transport network and near a rich palm-producing area south of Freetown. The groundnut and rubber areas behind Conakry in what is now Guinea stimulated the further development of this rival port north of Freetown. Nevertheless, the early advantage of accommodating larger ships because of the physical suitability of its harbour, the special warehousing and wholesaling arrangements prevailing in Freetown because of, among other things, British government interference, and institutional factors worked effectively in drawing trade to Freetown, illustrating how this city in particular helped to co-ordinate and augment trade throughout its vast hinterland in the 19 th Century. The long-distance traders rarely sold their highvalue goods like gold, ivory and hides outside Freetown because this trade required specialized knowledge of quality and of European markets, and so a few large merchants monopolized buying; these specialized merchants were also among the few importers of such commodities as guns and powder, prized highly by long-distance traders. The big Freetown-based merchants, moreover, built ties with kings, chiefs and others who traded on the coast, and sought even through representatives in the Legislative Council to use British Government resources to facilitate trade through missions to the interior, and fêtes and stipends for chiefs who co-operated in trade. Therefore, as the 19th Century advanced, Freetown came to be considered by the indigenous African governments as the political and economic seat of a kingdom, and this by both smaller states and powerful kingdoms as distant as the Fouta Djallon in nowadays Guinea. Finally, besides integrating through commerce the different sociopolitical and economic systems in the war-like interior, Freetown further polarized 
trade through its growing non-farming population for which rice in particular was brought from coastal areas far to the north and south of Freetown, thus helping to link them with the city.

The integration and polarization processes set in motion throughout Freetown's vast hinterland were disturbed, however, by the competitive, colonialist territorial claims of the British and French governments lodging in Freetown and Conakry respectively. This led in the 1880s and 1890s to subsequent diversion of the high-value, longdistance goods movements away from Freetown, to the British government establishing in 1896 the Sierra Leone Protectorate in order to determine politico-administratively its legal area of tariffs and trade, and to government rail building in this area between 1895 and 1916. This, in turn, led big European companies, and Lebanese and Indian entrepreneurs to gradually take over the trading functions performed along the coast and in the interior by independent Europeans, and by Creole middlemen who formed (as an amalgamation of descendants of the early negro settlers and liberated, recaptured slaves) the westernized, black bourgeoisie originating in Freetown.

Lack of capital, in the first instance, prevented the Creole and European, Freetownbased businesses from achieving returns on large-scale operations that gave the big European companies increased internal economies. It also made it difficult for these small and medium businesses to take full advantage of external economies provided by rail and steamship transport, and by financial and other service agencies becoming increasingly grouped in Freetown.

For almost as quickly as the rail moved to a town, so did the Lebanese traders and European companies. By the 1920s, eight of the big businesses were represented by branches at Blama, seven at Pendembu, six at Segbwema, and three or four at several other commercial and administrative centres like Makeni, which four were the most important railway stations for palm kernel traffic in those days. The closer connection with Europe meant finally that Freetown became a centre of decisionmaking on placement of funds allocated by international companies, and the British government to their head offices in Freetown, and to branches and departments in the provinces along the railway line and in the rivers' estuaries. Thus, by the 1920 s Freetown was becoming the central place in a developing system of railway and river towns, superimposed upon the crystallized pattern of numerous war-towns.

In addition, the revolutionary development of minerals, mainly diamonds, iron ore and bauxite, since the 1930s have also to be mentioned, as well as the booming road transport developments, and government introduction of new cash crops such as cacao and coffee, which altogether with the concentration of educational facilities in the southern part of nowadays Sierra Leone have caused a strongly felt disparity between the southern Mende and northern Temne tribal areas.

\section{The rise to authoritarian dominance of traditional and new élites alike}

The vigour of the French encircling movements pressing into the interior from the Conakry base and threatening to interfere with the inland markets of the Sierra Leone Crown Colony in the same way as happened to the Gambia in what is now Senegal, forced the British colonial government to proclaim the Protectorate over the whole of Freetown's hinterland in 1896, and this forms the independent state of Sierra Leone today. Five administrative districts were initially provided for under the jurisdiction of five District Commissioners to be seated in towns which were traditionally the stockaded strongholds of leading chiefs. These war-towns, such as Bandajuma, Karene, 
Falaba and Panguma, already served before 1896 as major police centres on frontier roads ('pathways mainly for the use of hammocks') established by the British government. These war-towns functioned, then, as bases for British control over surrounding areas, i.e. the numerous chiefdoms of paramount chiefs and their confederacies. Military enforcement of the Protectorate Ordinance of 1896 stipulating suppression of slave-dealing, collection of a house tax, British arbitration in chiefs' local disputes, etc. was needed after the House Tax War or Mende Rising of 1898 , however, but did not change the pre-Protectorate viewpoint of the British colonial government, taking as axiomatic the need to maintain the chiefs' authority. In fact the British conception of indirect rule, introduced officially in 1937 in order to transform the earlier Protectorate administration which was officially deemed to be geared too much to the preservation of only law and order, would otherwise have been rather meaningless as a theory of colonial local administration supposed to fit, through the chiefs, new distributive tasks such as provision of goods and services to the rural and urban populace, construction of roads, schools, etc.

This first transformation in Protectorate administration merely increased the already existing points of friction between chiefs and the rural masses, and consequently enabled the chiefs even to modernize a fair part of their sources of authority and power. Chiefs pursued their own wealth, namely through forced or customary labour employed on their own land, through illicit taxes and extravagant administrative expenditures, and in this way provided themselves with modern houses, automobiles, etc., as was officially reported in consequence of the inquiry into peasant tax riots of 1955-56. Thus, despite the traditional, rural environment wherein chiefs performed their ruling functions backed by the British colonial government, their incomes and style of life were to have much in common with those of the modern urban groups; this turned out to be of significance for the 1950s when the Protectorate chiefs joined the newly educated Protectorate élite in forming the Sierra Leone People's Party, which under the leadership of Dr Milton Margai became, after independence in 1961, the dominating political party until the general elections of March 1967 when the opposition party under the leadership of Mr Siaka Stevens took over after a military interregnum of 13 months in 1967-68. The consequences of a fusion of chiefs and the new Protectorate élite, mainly civil servants of direct kin of these chiefs, could be foreseen already in the 1950s: ruling families' domination in Sierra Leone's sociopolitical and economic development for years to be followed through an anxiously pursued, authoritarian single-party regime, constituting after independence a dictatorship of the Protectorate bourgeoisie which had replaced the privileged Creole bourgeoisie of the 19th-century Crown Colony of Freetown's Peninsula.

Next, it should be remembered that the British rulers, misguided by the chiefs' rôle in a socio-religious sense, recognized for politico-administrative conveniences that titles to land were implicitly vested in the rural community as a whole through the paramount chief or certain large family groups acting as custodians. In this way they favoured the chiefs and ruling families in an economic sense although in the traditional system the latter did not differ in this respect from the non-ruling families.

For as an outcome of the settlement phases between A.D. 1400 and 1900 ownership of land could originally be claimed only by the descendants of the hunters, warrior chiefs and warriors who first settled the country, and represent the nowadays ruling chiefs and families. Subsequent settlers, however, who were allotted land which had previously been brought under cultivation already by the original land owners, were considered to be under the protection of their landlord. Their right to occupy and 
use such land became progressively greater, the longer they remained with him. This second class of subsequent settlers and strangers, usually from other parts of the country, can be called land holders. As a general rule, the living memory is the only way of substantiating claims of landowners and land holders, whose latter rights are limited to personal occupation and use, i.e. usufruct of the soil.

The slaves of the second, war-like settlement phase were allocated land to eultivate on their own account and for their maintenance. It was recognized that their tenure, i.e. their right to use a part of their master's land, was secure as long as they satisfied his requirements. The domestic slaves were to become increasingly considered as land holders after the proclamation of the Protectorate in 1896. The tendency is finally observable for the land holders to merge into the upper class of land owners as time goes by.

The land tenure system as it exists today can therefore also be described as follows. Land rights are held by corporate family groups and are vested in the person of the heads of these groups, the symbolic and religious representation of these family heads' position being the single ancestral shrine sited in the compound of the head of the family - often in the township around which family lands and villages are clustered. The smallest areas to which land rights do refer, are commonly those of an individual man with his wife and children, whereas the largest areas sometimes comprise of several square miles and several villages around a town of a ruling family. In the latter case, individual family heads maintain virtually autonomous rights over their land within the total corporate family group, but these rights cannot be abinated out of the family group. Nevertheless within family lands a large number of families occupying and using land (originally land holders) do so by right of marriage relationships to the central patrilineal family, for instance, or simply as strangers and guests, but this status also is commonly strengthened by subsequent marriage ties. It was hinted at already that in the traditional situation rights to land originally derived from marriage ties developed through time into autonomous patrilineal rights, and that this process was essential to a viable disposition of land and human resources in a system where rights were subject to the rise and decline of power over people and areas. Thus rights of chiefs and chiefdom tribal authorities, more than fully recognized by the British colonial authorities in the early 20 th Century for politico-administrative purposes were those of a sanctioning, legal and political authority. In particular, then, young men are discouraged today from working the land under the prevailing rigid and authoritarian conditions, while the distributive functions of an independent government such as the launching of land improvement and mechanical rice cultivation schemes, even in a would-be co-operative setting, are hampered by the interests of local leaders in land, supported as these are by present party politics overriding administrators and technical officers.

Finally, due to the concentration of large-scale capital and managerial skill in the hands of expatriate, commercial and mining companies, the traditional and new élites are in a way predestined to turn to the government's human and material, but especially financial resources for both entrepreneurial and professional developments in their own interest. But government resources are limited, resulting in the use of corrupt methods to secure them by and in favour of the very politico-administrative élites and their allies which are seemingly still obligated to respect the claims of corporate family members in less favoured positions - these claims being grounded in socio-religious value patterns honoured by the tradition-bound masses in rural and urban areas alike. 


\section{Notes on eventual regionalizations of Sierra Leone (see Table 1)}

First of all, an hierarchic order of central places is to be observed today in Sierra Leone wherein at the one extreme numerous parent villages (201 to 500 inhabitants), and towns functioning as headquarters of (sections of) chiefdoms (501 to 1000 inhabitants) play an important role in the rural scene with its socio-political and economic micro-environments because of ruling and non-ruling families' interests in cash crop lands surrounding old ancestral towns and villages. At the other extreme. Freetown forms the primate city in the urban scene, and is the socio-economic and politicoadministrative centre of final decision-making for Sierra Leone as a whole, around which Makeni in the north, Koidu-Yengema in the east, Kenema in the southeast, and $B o$ in the south are grouped as the regional, administrative, economic and service centres. Thus, because of common interests of numerous rural central places - or poles of influence and dominance - in agricultural activities, a relatively homogeneous socio-political space is observable in Sierra Leone with a log-normal town size distribution and Freetown as the seat of central government; the former space is linked through party politics with the administrative and economic spaces with a primate city size distribution and Freetown as the very primate city (Berry, 1961).

Next, whereas the socialistic, revolutionary attack on the traditional, institutional framework - as this occurred during the 1950 s in Guinea, bordering on Sierra Leone remains to be evaluated, this solution is to be kept in mind only as a last recourse. Thus the viewpoint is taken here that evolutionary approaches accounting for the dominant position of traditional and new élites alike will fruitfully contribute to socioeconomic and political developments in Sierra Leone. Thereby, a short-term developmental view ( 5 to 7 years) is to be suggested instead of long-term perspectives because structural changes have nevertheless to be the target, and the results of the general elections of 1967 , i.e. the apparent defeat of the Sierra Leone People's Party, may form an historical turning- and starting-point hereto. Sierra Leone seems to be dependent, then, for developmental purposes to a large extent and for the time being on the dominant, private entrepreneurs and government administrators who are to be given incentives for investments and efforts focusing on exploitation of renewable resources by the central government, i.e. on the promotion of agriculture, and of agrobased, small-scale processing and manufacturing enterprises - and not as usual on the construction of houses, prestige, etc. Although trickling-down effects in favour of commoners in urban and rural areas will be consequently few, the central government may be faced with a splitting-up process of the powerful élites in antagonistic blocks (divide and rule) because of or through its regional development policies.

For these reasons the regions and sub-regions presently to be defined in Sierra Leone can be considered as tools in the hands of central and regional government authorities for playing the decision-making game on investments for societal purposes through a given set of priorities. Therefore, it is proposed herewith to place on top of the list with national priorities the over-all integration of various regional sub-systems into the national system through an economic policy aiming at import substitution, diversification of exports and domestic production, and at concentration of applied research, executive services' efforts, qualified personnel and funds on these sub-systems where investments could be expected to yield the highest returns as well as trickling-down or spread effects in favour of regional sub-systems not directly concentrated on. Herewith are taken into account - leaving attempts to international regionalization out of consideration - the fact that Sierra Leone is balancing on the edge of national 
bankruptcy, along with government proposals for infrastructural investments, in cooperation with the International Bank of Reconstruction and Development, in the national road transport system, a hydro-electric installation near the waterfalls of Bumbuna, etc., for a Kono development plan, and for the phasing out of the government railway, where due to road transport compctition and discrepancies between the total annual volumes of up- and down-traffic freight expenditures have been exceeding revenues annually since 1927 already as a rule.

In addition, the decreases and increases in importance have to be mentioned of (un)processed agricultural produce, and diamonds and iron ore in Sierra Leone's export basket: proportional change in percentages of the value of domestic exports from $29 \%$, and $39 \%$ and $31 \%$ in 1938 , to $16 \%$, and $62 \%$ and $21 \%$ in 1965 , respectively.

It is noteworthy that Freetown today handles mainly the imported, relatively highvalue manufactured goods (merchandize like building materials, petroleum, etc., but also rice and other provisions), while specialized mineral ports like Pepel in the Sierra Leone river's estuary, and Point Sam in the southern Sherbro river transport system handle the bulk of low-value, mineral exports.

This leads the author to suggest a development corridor to be aimed at between two core regions (Friedmann, 1965, p. 41-43), between the northwestern core region of the Freetown and Bullom Peninsulas and of the coastal rice growing areas along the lower courses of the northern Scarcies rivers on the one hand, and the herewith proposed core region of the Kono District in the east on the other hand. By suggesting this, it is realized that a blank cheque is in fact being signed for future developments to be strongly tied up with the Tonkolili road under construction between Magburaka, Matotaka and the mechanized diamond mining areas of Kono District. But also questionable is the availability of private capital for investments in Sierra Leone, instead of sending savings abroad, by Lebanese traders and diamond-based foreign enterprises, as are the special qualities and skills of the tribally distinctive, Kono labour force trained on the spot in various industries and trades, but well aware, too, of its macroeconomically strategic position in and around the diamond mining areas.

It might be obvious, nevertheless, that for the time being national development efforts are most likely to be concentrated spatially along two axes: the existing Freetown - Bo - (Kenema) highway connection to the south, and the Freetown - Lunsar (Makeni) - Magburaka - Kono highway connection to the east. And, indeed, there are historically explainable, socio-economic and politico-administrative forces at work conditioning in the short run nothing else than a spatial development model for Sierra Leone clearly and strongly centered on the Freetown, and southern, diamond mining and cash-crop growing, Mende areas alone. These forces are not easily to be counterbalanced by those being felt and heard outside Freetown in the non-Mende, Northern and Eastern Provinces in particular, but which may be reinforced and even reconciled in a politically and socio-economically controlled manner by consciously handling the alternative development model suggested by the author. In case the Northern Region presently to be defined might be deemed to have attracted too little attention in this alternative model - leaving aside the functions to be performed herein by the Eastern and Southern Regions - other alternative, spatial development models and, consequently, regional development strategies should be conceived as guidelines for economic and social investments from private and public sources.

Finally, it is thought to be consistent with aforemade remarks, if in all the nine sub-regional units and three regional sub-systems hereafter to be defined the existing and/or future cash crop patterns are focused on, and thus neither the agricultural 
subsistence sector of Sierra Leone's economy, nor the government sector which actually depends for its revenues upon the economically productive capacities of either the cash-cropping peasantry, or expatriate capital and entrepreneurs involved in mining and commercial activities.

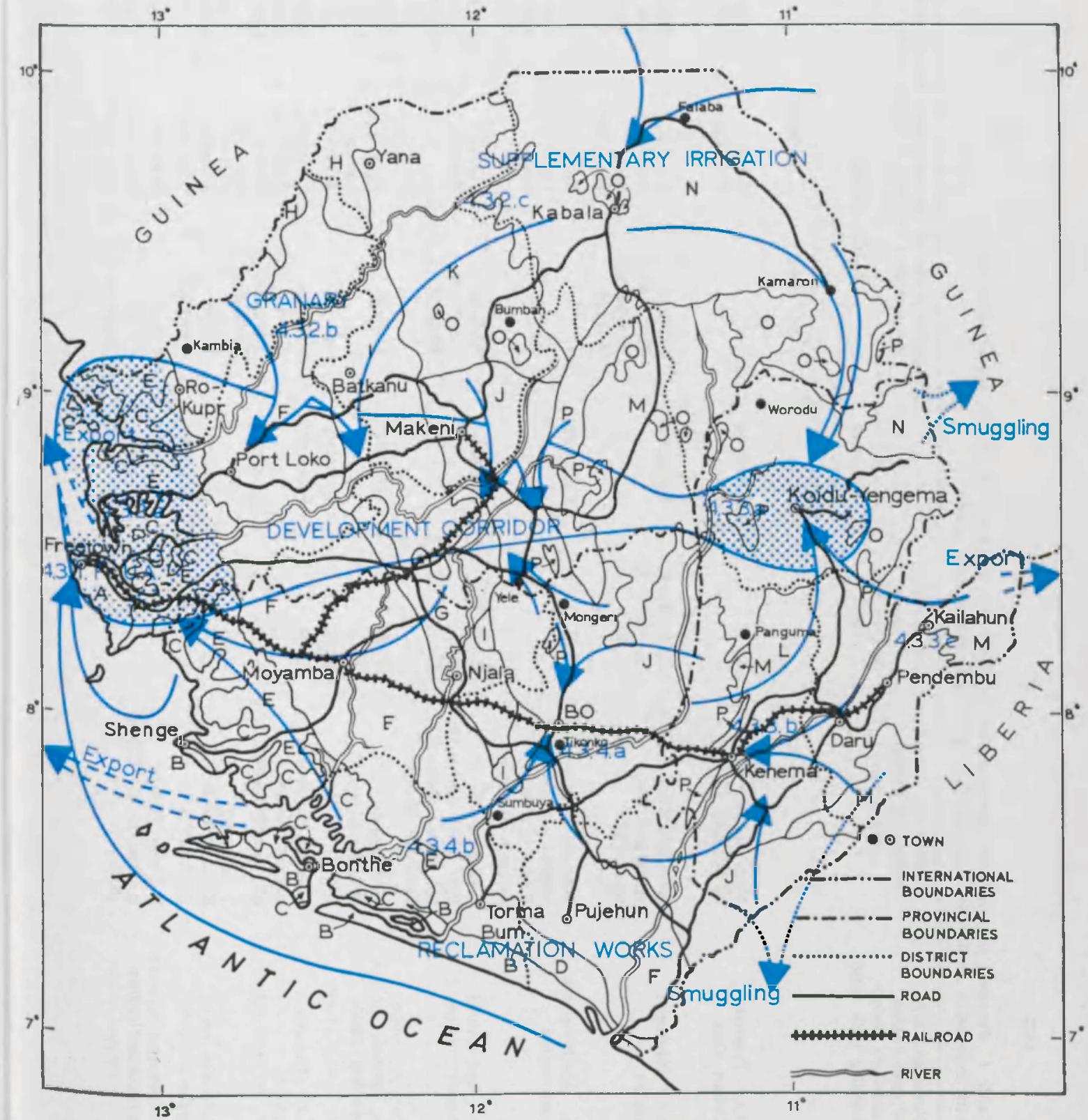

Map of Sierra Leone (Soil provinces; Dijkerman, 1967). Scale 1:2,600,000. 


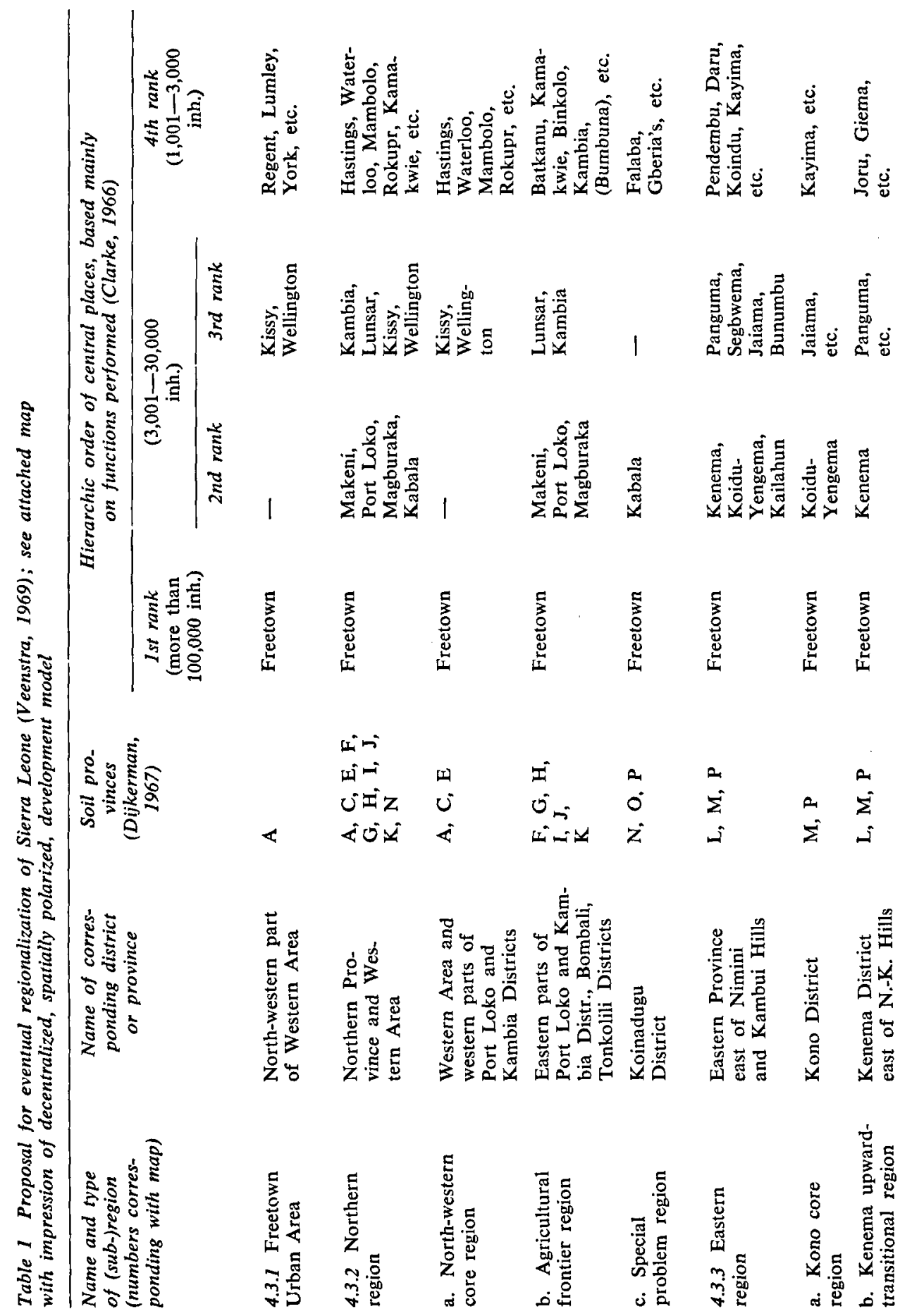




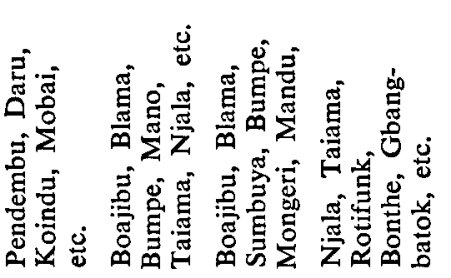

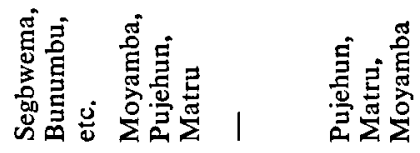

竝

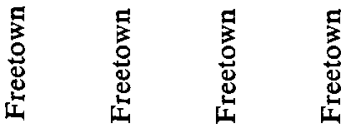

Aं०

$\sum$ णिं vis

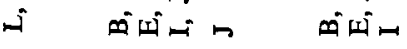

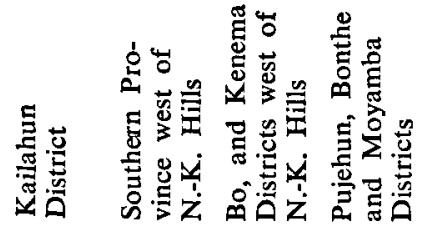

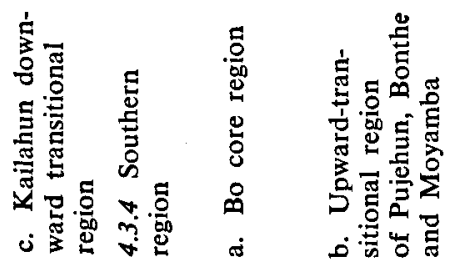

Neth. J. agric. Sci. 18 (1970) 


\section{Further qualifications, and development strategies (Dijkerman, 1967; numbers corres- pond with map)}

Ad 4.3.1 Area unchallenged in its primacy in all aspects of Sierra Leone's life: capital city, chief port, chief area of commercial, industrial, administrative, service and political activities, highest degree of urbanization, etc.

Ad 4.3.2.a Core region suggested in view of flourishing trade from cluster of urban population along lower courses of Scarcies, and from Bullom Peninsula with Freetown Urban Area, in locally produced rice, vegetables, cassava, pineapples, citrus, poultry products, pork, etc., and in fish of a pellagic, estuarine and inshore character. Vegetable growing only to be encouraged in some valleys of Freetown's Peninsula Mountains, and touristic potential to be developed of this Peninsula's beaches. Reclamation works to be undertaken along Scarcies in mangrove swamps for rice cultivation. Citrus, bananas and pineapples, rice and vegetables, and coconuts and cassava to be grown on the uplands, in the inland valley swamps, and on the beach ridges respectively. The urban cluster of population around Mambolo and Rokupr to be looked at as to be promoted in rank, and made more independent of the dominant Freetown Urban Area, because of its mainly agro-based industrial, and politically explosive potentials.

Ad 4.3.2.b Spread effects of Marampa/Lunsar iron ore mine are known to have faded out today since exploitation started in the 1930s. Permanent land use patterns to be introduced in the eastern parts of this agricultural frontier region: tree crops to be grown on upland slopes, rotational farming on riverain terraces, and animal-drawn rice cultivation in inland valley swamps. Makeni possibly to be indicated as future agro-based industrial centre in addition to its commercial, administrative and service functions. Swamps and river terraces of boli-lands west of Makeni to be predestined as future national 'granary' (rice, groundnuts, cassava, sweet potatoes, beans, etc.) through adequate fertilizing, mechanical ploughing, and water control measures.

Ad 4.3.2.c Bearing in mind its inaccessibility, this special problem region deserves special attention, not in the last place for strategic reasons: situated along the national northern and northeastern borders with Guinea, and diamonds and cattle having been smuggled over these borders for decades already. Promotion of mechanical rice cultivation, road construction, animal husbandry, citrus, vegetable and tobacco growing, etc. to be taken in hand in an integrative way.

Ad 4.3.3.a Along the proposed Kamaron-Worodu road connection are to be supplied from 4.3.2.c (partly irrigated, short-duration) cotton, citrus, and jute substitutes for purposes of small-scale processing, canning and manufacturing in the absolutely to be improved, urban environment of Koidu-Yengema area. As growing consumer market this area will need poultry and livestock products, rice, groundnuts, vegetables, etc. produced in $4.3 .2 . \mathrm{b} / \mathrm{c}, 4.3 .3 . \mathrm{b} / \mathrm{c}$, and its direct surroundings.

Ad 4.3.3.b/c Development of labour-intensive type of water-controlled, inland valley swamp farming (rice, vegetables, maize) to be stimulated in Kailahun and Kenema Districts, and improvements in upland cocoa, coffee, oil-palm and timber production, in order to bring about more stable land use and employment patterns, as well as resettlement of Kissy families from their own, densely populated, tribal areas to other sub-regions of Sierra Leone. In addition to the Forest Industries' factory in Kenema city agro-based industries are to be encouraged, such as an instant coffee factory.

Ad 4.3.4.a Due to native diamond digging, mechanized foreign diamond mining and cash crop developments in Eastern Region during 1940s and 1950s, Bo core region lost ground in a socio-economic sense. Bo city's urban functions in particular, initiated during early days of British colonial Protectorate, are to be reinforced by including native diamond digging chiefdoms west of Nimini and Kambui Hills within the sphere of influence of Bo city. Thus, attention is to be paid to extension of feeder road to Njala-Kamboya up to Sewa river for connection with Boajibu, and to upland cocoa, coffee and oil-palm cultivation in the Bo District as a whole, as well as to water-controlled, mixed swamp farming (combination of small-scale pig raising, poultry farming, and rice, vegetable and maize growing) based on good water resources at the western foots of Kangari Hills along road Bo-Yele.

$A d$ 4.3.4.b Besides integrated policies for expansion of water-controlled, inland valley swamp rice and vegetable farming area, and of suitable upland areas under rubber, oil-palm and coffee cultivation, or forest reserves, a development programme is needed for the Pujehun District; this is needed to tackle in a strip of 10 to 20 miles wide and running parallel to the Atlantic coast all technicalities of empoldering, reclamation works, dikes, and of waterways for transport of agricultural produce on one side, and of mechanical rice cultivation, sugar-cane, banana, 
pineapple, citrus and coconut growing on the other side. For piassava from Pujehun and Bonthe Districts is to be struck from the list with Sierra Leone's exports as a vegetable fibre, so that through import substitution sugar-cane in particular is to become a domestic earner of foreign exchange in the hands of peasant farmers and small-scale processors.

\section{Acknowledgments}

The author is indebted to Dr J. G. M. Hilhorst and Mr D. M. Dunham for their critical remarks.

\section{References}

Berry, B., 1961. City size distribution and economic development. In: Bert F. Hoselitz (Ed.), Economic development and cultural change. University of Chicago.

Clarke, J. I., Nelson, S. J. A. \& Swindell, K., 1966. Sierra Leone in maps. University of London Press, London.

Friedmann, J. R. P., 1965. Regional development policy: A case study of Venezuela. M.I.T. Press, Cambridge, Mass.

Odell, R. T. \& Dijkerman, J. C., 1967. Properties, classification, and use of tropical soils, with special reference to those in Sierra Leone. Mimeographed. Njala University College, Freetown.

Veenstra, J., 1969. The relevance of the Centre-Periphery model for more than 150 years of preindustrial developments in Sierra Leone, West Africa: towards a regionalisation of national development efforts. Institute of Social Studies, The Hague. 